\title{
lgor lvašković
}

\section{DILEME SPREMLJANJA UČINKOVANJA NAČRTOVANEGA UČENJA NA ORGANIZACIJSKO USPEŠNOST}

\section{POVZETEK}

Prispevek proučuje problematiko spremljanja rezultatov učenja v organizacijskem kontekstu in poskuša ponuditi odgovor na vprašanje, zakaj in kako na organizacijski ravni spremljamo učinkovanje načrtovanega učenja na uspešnost. S pomočjo pregleda literature na področju poslovnih ved avtor sistematizira razprave in ugotavlja, da pri tem zaradi kompleksnosti in zahteve po uporabi različnih metodoloških prijemov še vedno obstaja veliko nesoglasij. Kljub temu meni, da je spremljanje nujno, saj je prvi pogoj za identifikacijo pomembnih točk dela, pojasnjuje pričakovanja vodstva do zaposlenih in spodbuja njihovo kreativnost. V sklepu avtor poudarja, da je pri spremljanju treba poznati kontekst organizacije, proces načrtovanega učenja in njegove rezultate pa je treba spremljati večdimenzionalno ter na več ravneh. Pri tem je nujno ohraniti enostavnost izvedbe spremljanja in razumljivost ugotovitev.

Ključne besede: učenje, strategije, uspešnost, delovno mesto, spremljanje, učinki

\section{THE DILEMMAS OF MONITORING THE EFFECTS LEARNING HAS ON OR- GANISATIONAL PERFORMANCE - ABSTRACT}

The article examines the issues of monitoring the effects of learning in an organisational context and attempts to answer the following question: "Why and how can we monitor the effects learning has on organisational performance?" The author provides a review of the relevant literature from the field of business management and finds many discrepancies that are due to the complexity and the use of various methodological approaches. Nevertheless, the author establishes that monitoring is necessary because it makes it possible to identify certain key points in the working process, clarifies the expectations management has of the employees and encourages their creativity. At the same time, the article emphasizes that the monitoring process requires knowledge of the organisational context, and the learning process and its effects need to be studied on a multidimensional and multi-level basis, while the monitoring process itself should be simple to implement and the findings easy to understand.

Keywords: learning, strategies, performance, workplace, monitoring, effects

Doc.dddr. Igor Ivašković, Ekonomska fakulteta, Univerza v Ljubljani, igor.ivaskovic@ef.uni-lj.si 


\section{UVOD}

V preteklem stoletju se je razvila posebna znanstvena disciplina o odnosu med organizacijo in posameznikom, ki v njej deluje. V slovenščini poznamo več prevodov angleškega termina human resource management, ${ }^{1}$ kot kratica pa še vedno prevladuje uporaba $» H R M \ll$. Če izhajamo iz Lipovčeve (1987) opredelitve organizacije, lahko HRM opredelimo kot razumevanje odnosov med posamezniki, nalogami in organizacijo, pri čemer je namen vplivanja na ta razmerja povečevanje uspešnosti (z organizacijskega, individualnega in družbenega vidika). HRM torej zajema vsako dejavnost, ki vključuje odnos delavca in delodajalca, pri čemer je fokus na procesih analize dela in identifikaciji organizacijskih potreb, privabljanju in izbiri ljudi, njihovem uvajanju v delo in usposabljanju ter končno tudi na plačevanju oz. nagrajevanju.

Načrtovano učenje ${ }^{2} \mathrm{v}$ organizacijskem kontekstu običajno poteka $\mathrm{v}$ okviru dejavnosti HRM, pri čemer lahko govorimo o andragoškem procesu, ki je namenjen praktičnemu učenju s ciljem povečanja uspešnosti organizacije. Tu je nujno poudariti, da dejavnost HRM ni omejena samo na kadrovski oddelek, temveč se nanaša na vse odnose med ljudmi, ki so usmerjeni k pridobivanju in razvoju kompetenc zaposlenih. Učenje v organizacijskem kontekstu z omenjenim ciljem povečanja končne uspešnosti organizacije se v najožjem pomenu opredeljuje kot usposabljanje, saj gre za razvijanje kompetenc, ki jih zaposleni potrebuje pri opravljanju konkretenega dela (Možina idr., 1998). Vendar se je treba zavedati, da proces načrtovanega učenja $v$ organizaciji poteka $v$ bistveno širšem kontekstu, tudi zunaj delovnega mesta. Predvsem v nerutinskih dejavnostih v nepredvidljivem okolju pa se učenje pogosto fokusira na razvoj kompetenc, ki v danem trenutku niso neposredno povezane s konkretnim delovnim mestom. Ravno takšno širše opredeljeno učenje $\mathrm{v}$ organizacijskem kotekstu obravnava pričujoči prispevek.

HRM kot načrtna dejavnost ima namen mobilizirati in upravljati oz. usmerjati znanje s ciljem uresničevanja organizacijskega poslanstva (Nicolini, Gherardi in Yanow, 2003). Procesi HRM so posledično usmerjeni na razvoj delovnih kompetenc, kar vključuje pridobivanje znanja, veščin, povečanje motivacije ter razvoj samopodobe in dispozicij posameznika za delovanje. Ker so kompetence kompleksni in dinamični konstrukti, teh ni vedno lahko meriti, posledično pa prihaja tudi do težav pri spremljanju učinkovanja učenja $\mathrm{v}$

1 V slovenskem prostoru še vedno ne obstaja konsenz o prevodu »human resource management«, kar se najbolj kaže v različnih interpretacijah izraza »management «(Celinšek, 2015; Rozman, 1996). Med pogostejšimi prevodi lahko zasledimo »ravnanje z ljudmi pri delu«, »ravnanje s človeškimi viri«, »upravljanje človeških virov«, »management človeških virov«, »kadrovski management«itd. Rozman (1996) meni, da je izbor besede »ravnanje« v tem kontekstu najprimernejši, saj se beseda »upravljanje« nanaša na funkcijo, ki je v domeni lastnikov. Obenem je izbor izraza »ravnanje z ljudmi pri delu« nekoliko primernejši od »ravnanja s kadri« ali »kadrovskega managementa«, saj se HRM nanaša na bistveno širšo dejavnost ravnanja z ljudmi, ne zajema namreč samo tistih, ki sodijo med kadre določene organizacije.

2 Pri tem je treba nujno omeniti, da se sicer večina učenja $\mathrm{v}$ sodobnih organizacijah odvija spontano, in sicer kot del delovnega procesa, mimo oddelkov HRM in njihovih aktivnosti. Temu se v zadnjih 20 letih tudi v HRM-literaturi namenja več pozornosti (Skule, 2004). Res je, da se samo učenje težko meri, ključna za delodajalca je predvsem identifikacija okoliščin, ki privedejo do pozitivnih posledic. 
organizacijskem kontekstu na uspeh orgaizacije. Članek ima namen prispevati k razpravi o tej problematiki, in sicer $\mathrm{z}$ iskanjem odgovorov na vprašanje, zakaj in kako na organizacijski ravni spremljamo učinkovanje načrtovanega učenja na uspešnost. Pri tem gre primarno za analizo učinkov učenja na organizacijski in sekundarno na individualni ravni. Razvoj takšnega spremljanja je namreč doživel ekspanzijo v drugi polovici 20. stoletja, a pri tem zaradi kompleksnosti in zahteve po uporabi različnih metodoloških prijemov ${ }^{3}$ še vedno obstaja veliko nesoglasij glede smiselnosti spremljanja.

S pomočjo polsistematiziranega pregleda literature, predvsem kvantitativnih HRM-študij s preloma stoletja, v skladu s priporočili avtorjev Snyder (2019) ter Wong, Greenhalgh, Westhorp, Buckingham in Pawson (2013) prispevek sistematizira argumente za spremljanje učenja in njegovih učinkov ter aplicira mnenja zagovornikov univerzalnih HRM-praks in na drugi strani nasprotnikov te teze na problematiko spremljanja učenja $\mathrm{v}$ organizacijskem kontekstu. Pri tem je poleg že omenjenega raziskovalnega vprašanja temeljni cilj ugotoviti, ali obstajajo univerzalne smernice za spremljanje učinkov učenja v organizaciji. Prvi del prispevka opredeljuje pomen učenja v organizacijskem kontekstu, v drugem sledi razprava o tem, ali je lahko učenje strateški dejavnik konkurenčne prednosti za organizacijo. Na koncu so v ospredje postavljene dileme, ki se pojavljajo pri merjenju, ter navedena priporočila za spremljanje učinkovanja učenja na organizacijsko uspešnost.

\section{ORGANIZACIJSKA SPOSOBNOST UČENIA KOT STRATEŠKI DEJAVNIK KONKURENČNE PREDNOSTI}

Širitev procesov liberalizacije, nova tehnološka odkritja, povečevanje zahtevnosti potrošnikov in drugi procesi, ki jih običajno prištevamo v kontekst globalizacije, silijo organizacije k prilagajanju in pospešenemu iskanju svoje konkurenčne prednosti. Feurer in Chaharbaghi (1995) sta konkurenčno prednost opredelila kot redek dejavnik ali težko posnemljivo kombinacijo več dejavnikov, zaradi katerih je organizacija uspešnejša od drugih. Čater (2003) pri opredelitvi konkurenčne prednosti povzema njeni dve bistveni lastnosti, in sicer prednostni položaj organizacije in relativnost. Medtem ko se prednostni položaj nanaša na superiorno pozicijo organizacije, relativnostna komponenta opozarja, da je konkurenčno prednost mogoče opaziti in izmeriti le s primerjanjem te lastnosti pri več organizacijah. Če izluščimo bistvo opredelitev, ki pojasnjujejo, kaj vse je potrebno, da bi neki dejavnik izpolnjeval kriterije za konkurenčno prednost, lahko zapišemo naslednje (Wright in McMahan, 1992):

3 V HRM-literaturi lahko zaznamo dilemo, ali prilagajati študije in metode raziskovanja objektom, ki jih analiziramo, ali pa raje sprejeti univerzalna pravila o pristopu k obravnavi problematike HRM. Delaney in Huselid (1996) ugotavljata, da se kot problem kaže ravno dejstvo, da je zelo malo študij HRM, ki bi uporabile povsem enake metodološke pristope in orodja. Sočasno je to do določene mere razumljivo, saj so sklopi praks HRM močno odvisni od panoge, strukture zaposlenih, tehnologije in od številnih drugih dejavnikov, ki ne omejujejo samo managementa pri sprejemanju in izvajanju procesov HRM, temveč tudi raziskovalce pri merjenju njihovih učinkov. 
1) dodajati mora pozitivno vrednost organizaciji (omogočati pozitivne ekonomske koristi);

2) mora biti edinstven ali vsaj redek;

3) ne sme biti enostaven za posnemanje in

4) je nenadomestljiv oz. ne sme imeti zadovoljivih nadomestkov.

Po Barneyju (1991) lahko vire konkurenčne prednosti razdelimo v fizične, človeške in organizacijske. Medtem ko med prve prištevamo predvsem tehnologijo, zgradbe, opremo, geografsko lokacijo itd., so ključni organizacijski dejavniki lahko formalna organizacijska struktura, formalno in neformalno načrtovanje, kontrola in koordinacijski sistemi, neformalni odnosi med skupinami znotraj organizacije ter med organizacijo in njenim okoljem. Človeški viri na drugi strani lahko omogočajo konkurenčno prednost na podlagi znanja, pridobljenega z usposabljanjem ali izkušnjami, inteligentnosti in medčloveških odnosov (Pološki-Vokić, 2003; Lazović, 2013). Danes relativno majhen delež podjetij lahko gradi konkurenčni položaj izključno na edinstveni lokaciji ali na boljši dostopnosti surovin, ki jih je nemogoče ali ekonomsko nesmotrno umetno ustvariti, zato nematerialna lastnina dobiva vse večji pomen (Hitt, Bierman, Shimizu in Kochhar, 2001; Lazović, 2013). V literaturi s področja managementa se za nematerialno lastnino najpogosteje uporablja izraz intelektualni kapital, ki ga Dovžan (2003) opredeljuje kot najpomembnejše proizvodno sredstvo. Delimo ga na človeški in strukturni, pri čemer slednjega sestavljata organizacijski kapital in kapital kupcev (Stewart, 1997). Raven nematerialne vrednosti organizacije lahko okvirno izmerimo že s primerjavo računovodske in tržne vrednosti organizacije. V obdobju zadnje globalne ekonomske krize, manjšega zaupanja in posledično manjšega obsega trgovanja je bilo razmerje med tržno in knjižno vrednostjo sicer manjše kot $\mathrm{v}$ začetku stoletja, vendar so tudi v tem obdobju najboljša podjetja še vedno povečevala to razliko v prid tržne vrednosti. Na podlagi tega lahko sklepamo, da ne le podjetja, temveč tudi različne vladne organizacije vse večji poudarek dajejo ustvarjanju nematerialne lastnine po načelih učeče se organizacije (Fenwick, 1998). To velja celo za kapitalsko intenzivne, še bolj pa za tiste organizacije, katerih bistvo delovanja so znanje, odnosi s kupci itd. (Mayo, 2001).

Spreminjanje vrednosti materialne (fizične) in nematerialne lastnine organizacije je v največji meri odvisno od ljudi. Zaposleni namreč upravljajo fizično lastnino, s čimer poskušajo ohraniti čim višjo raven njene začetne vrednosti, sočasno pa je ravno od sposobnosti, motivacije, ustvarjalnosti in veščin ljudi odvisno ohranjanje oz. povečevanje nematerialne lastnine (Mayo, 2001; Brečko, 2007). Cascio (1998) meni, da je tudi na ravni naroda oz. države ključni dejavnik konkurenčnosti količina veščin in vsota nakopičenega znanja delovne sile, saj tega dejavnika ni mogoče enostavno posnemati, v stvarnosti pa pogosto kaže nižjo raven mobilnosti od tehnologije (fizične), surovin, kapitala in informacij. Pološki-Vokić (2003) k temu poleg inteligentnosti delovne sile dodaja še lojalnost in delovni zagon. Dostopnost strojev in opreme torej ne more biti dejavnik diferenciacije v takšni meri, kot je to sposobnost njihove učinkovite rabe. Zato ne preseneča, da hitro okreva tisto podjetje, ki je ostalo brez strojev, a ohranilo veščine in znanje, česar ni možno pričakovati 
od podjetja, ki je izgubilo usposobljeno delovno silo. Ravno tako so ljudje ključni dejavnik, ki odseva sposobnost prilagajanja organizacije na spremembe v okolju, saj lahko sprejemajo strateške in taktične odločitve. Samo ljudje lahko ustvarjajo nove proizvode, storitve in tehnologije. Ljudje so še vedno najbolj zanesljivi tudi pri identifikaciji družbenih sprememb v okolju in pomenijo tisti dejavnik, ki dejansko uvaja spremembe v organizacijo. Da so ljudje v vse večjem deležu organizacij edini dolgoročni vir konkurenčne prednosti, lahko potrdimo tudi s preverjanjem izpolnjevanja prej navedenih štirih temeljnih kriterijev vira konkurenčne prednosti:

1) Delo ljudi lahko ustvarja dodatno pozitivno vrednost $v$ organizaciji. To izhaja iz dejstva nehomogenega povpraševanja po delu in ponudbe dela. Že znotraj ene organizacije je namreč treba opravljati različna dela, ki zahtevajo različno znanje in veščine. Ravno tako se posamezni ponudniki dela razlikujejo glede ponudbe lastnega znanja in veščin. Posledica tega je razlika v posameznih prispevkih $\mathrm{k}$ uspešnosti organizacije in tudi razlika $\mathrm{v}$ uspešnosti med organizacijami.

2) Znanje in veščine so lahko edinstveni ali vsaj dovolj redki, da lahko pomenijo razliko do konkurence. Tudi za potrjevanje te trditve je ključni argument heterogenost ponudbe veščin in znanja. Ob predpostavki normalne distribucije delovnega potenciala lahko sklepamo, da je kakovostna delovna sila redka dobrina.

3) Človeški potencial je težko posnemati, kar je pogosto posledica otežene identifikacije konkretnega človeškega znanja in veščin, ki omogočajo konkurenčno prednost. Še težji od identifikacije pa je prenos znanja in veščin na drugo osebo oz. na zaposlene v konkurenčni organizaciji. Iz tega izhaja tudi teza, da same odločitve vrhnjega managementa lahko ponujajo le kratkoročno konkurenčno prednost, ker je te odločitve lažje posnemati, zato naj bi bil vir konkurenčne prednosti lahko le celoten sklop znanja in veščin v podjetju (Wright, McMahan in McWillams, 1994). Barney (1991) oteženo posnemanje utemeljuje s specifičnimi zgodovinskimi pogoji, ki jih ima točno določena organizacija. Konkurentom je namreč zelo težko posnemati način razvoja določene organizacije. Posledično je tudi težko vzpostaviti pogoje oz. specifično okolje, znotraj katerega se viri konkurenčne prednosti pojavijo. Sočasno je vzročno-posledična povezava med neotipljivimi viri, kot je na primer kultura organizacije, in konkurenčno prednostjo zamegljena oz. je tako kompleksna, da je na kratek rok njeno posnemanje nemogoče. Tretji dejavnik, ki preprečuje posnemanje, je kompleksnost družbenih pojavov, kar pomeni, da določenega družbenega konteksta ni mogoče prenesti iz ene organizacije v drugo, saj vodstva na to nimajo vedno možnosti vpliva.

4) Na dolgi rok človeškega potenciala ni možno nadomestiti z drugimi resursi. Pološki-Vokić (2003) to utemeljuje z dejstvom, da je človeško delo sicer na kratek rok zamenljivo s tehnologijo, vendar je ta dostopna vsem, ki imajo dovolj finančnih sredstev. Pri tem je treba poudariti, da v procesu alokacije kapitala slednji sledi redkemu znanju, zato se v končni fazi dve podjetji lahko razlikujeta le na podlagi znanja in veščin ljudi, ki tehnologijo uporabljajo.

Zdi se torej, da je ravno sposobnost organizacije pri spodbujanju učenja zaposlenih ključnega pomena za njeno konkurenčno prednost. 


\section{POLOŽAJ UČENIA MED ORGANIZACIJSKO STRATEGIJO IN USPEŠNOSTJO ORGANIZACIJE}

V zadnjih 30 letih je bil narejen izjemen napredek v raziskovanju zveze med oblikami učenja, ki jih uporabljajo različni pristopi HRM, in organizacijsko uspešnostjo. Čeprav je v tem kontekstu nastalo več pojasnjevalnih modelov, večina avtorjev še vedno izpostavlja t. i. črno škatlo (»black box«), ki predstavlja prostor neznanih povezav in pravil, katerega razkrivanje bi lahko omogočilo pojasnjevanje vzročnih zvez. Becker in Gerhart (1996) sta zato $\mathrm{v}$ ospredje postavila pomen identifikacije neposrednih posledic učenja, ki vodijo do končne organizacijske uspešnosti. V tem kontekstu Boxall in Purcell (2000) trdita, da tudi posnemanje posameznih praks $v$ drugem podjetju ne bo učinkovalo enako, če so $\mathrm{v}$ slednjem drugačne okoliščine kot $\mathrm{v}$ prvem. Zato je pomembno poudariti razlikovanje med ljudmi oz. človeškim kapitalom in procesi učenja v okviru dejavnosti HRM. Prvi posedujejo znanje in veščine, medtem ko izbrana oblika učenja lahko le pripomore $\mathrm{k}$ njihovi učinkovitejši rabi in spodbuja njihov nadaljnji razvoj. S pomočjo učenja pa se ne pridobivajo le znanje in veščine, temveč se ustvarjajo vedenjski vzorci in stališča, ki sooblikujejo pojave, kot sta kultura in klima, ki jih je praktično nemogoče posnemati. Na drugi strani učenje v okviru organizacije deluje tudi na človeški kapital, saj omogoča boljši izkoristek in pridobitev znanja, veščin ter razvoj talentov pri vseh članih organizacije, ne le tistih najbolj talentiranih. Kljub temu proučevanje vpliva učenja $\mathrm{v}$ organizacijskem kontekstu na uspešnost organizacije še vedno odpira številne dileme. Učinki na tej relaciji pogosto niso neposredni in so opazni šele na daljši rok. Pri tem se postavljata vprašanji, kako konkretizirati bistvo te povezave in katere druge dejavnike je treba vključiti v proučevanje.

Glede učenja v organizacijskem kontekstu HRM-literatura ponuja kar nekaj različnih pojasnjevalnih modelov. Še vedno sta najbolj znana t. i. michiganski in harvardski model. Prvi daje večji pomen notranjim dejavnikom uspešnosti, predvsem vlogi managementa. Tako na primer Likert (1967, v Pološki-Vokić, 2003) pri identifikaciji kritičnih dejavnikov učenja opredeljuje: 1) vedenje managerja, 2) organizacijsko strukturo in 3) vedenje podrejenih kolegov. Preostale dejavnike (percepcije, komuniciranje, motiviranje itd.) označuje kot posrednike oz. kot mediatorje med vzročnimi dejavniki in končnimi rezultati. Na drugi strani harvardski model upošteva širši kontekst, tudi okolje, na katerega vodstvo organizacije pogosto nima pomembnejšega vpliva. Iz tega izvira tudi razhajanje med univerzalističnim pristopom, ki domneva, da obstajajo določene »najboljše prakse«, ki jih je mogoče uporabiti v vseh organizacijah (Pfeffer, 1998), in situacijskim pristopom, ki izhaja iz domneve, da se morajo HRM-prakse in v okviru tega tudi učenje prilagajati danemu okolju (Van Waeyenberg in Decramer, 2018).

Proučevanje vzročno-posledične zveze med strategijo in uspešnostjo ter vloge, ki jo ima na tej relaciji učenje, se je poleg pojasnjevanja v okviru teorije boljšega pristopa $\mathrm{k}$ virom (resource based view - RBV) naslanjalo tudi na druge perspektive. $Z$ vidika behavioristične teorije je naloga učenja v okviru HRM ne samo prenos znanja in pridobivanje veščin, temveč tudi uravnavanje stališč in vedenja zaposlenih, da bodo ta v skladu s strategijo in 
načrtovano uspešnostjo (Schuler in Jackson, 1987). Procesi učenja imajo s te perspektive primarno nalogo oblikovati vedenjske lastnosti in vzorce zaposlenih (npr. ustvarjalnost, nagnjenost $\mathrm{k}$ sprejemanju večjega tveganja, povečevanje sodelovanja in prenašanja znanja itd.), medtem ko je manjši poudarek na izboljšanju njihovih veščin, povečanju znanja in sposobnosti. Behavioristični pogled predpostavlja, da vsaka strategija zahteva specifične vedenjske vzorce ter da načeloma ne obstajajo splošno bolj in splošno manj učinkovite prakse učenja v okviru celotnega spleta HRM, zato ima ta teorija svoje korenine v situacijski teoriji (Collins in Clark, 2003). Podobno kot RBV tudi ta pristop temelji na tezi, da je treba proučevati celotne sisteme in ne le posamezne prakse, pri čemer mora biti vsak sistem prilagojen potrebam posamezne organizacije. V kontekstu merjenja učinkov učenja daje ta šola večji poudarek behaviorističnim mediatorjem na skupinski oz. organizacijski ravni, ki naj bi imeli vlogo posrednika praks učenja v kontekstu procesov HRM h končni uspešnosti organizacije.

Institucionalni pristop, ki temelji na šoli industrijske organizacije, poudarja, da se organizacije soočajo z različnimi institucionalnimi ureditvami, ki imajo lahko zakonsko podlago ali pa jih narekujejo drugi kulturno pogojeni dejavniki. Starejši klasični institucionalni pristop izraža dvom glede možnosti vplivanja vodstva na uspešnost organizacije, medtem ko ima t. i. novi institucionalizem nekoliko manj tog pogled. Po slednjem se znotraj enega kulturnega okolja različne organizacije soočajo z izomorfičnimi silnicami, ki silijo organizacije k homogenizaciji (Dimaggio in Powell, 1983). Vodstva pri tem sprejemajo strategije in uravnavajo procese $\mathrm{v}$ organizaciji $\mathrm{v}$ skladu $\mathrm{z}$ zahtevami institucionalnega okolja. Do tega naj bi prihajalo tudi na področju učenja na delovnem mestu (Hasmath in Hsu, 2014). V tem kontekstu naj bi bila vloga učenja znotraj organizacije, ob upoštevanju institucionalnih silnic v obliki različnih regulativ in kulturnih značilnosti ljudi, prilagajati procese znotraj organizacije tako, da bodo na najlažji način doseženi želeni cilji. Teorija transakcijskih stroškov upošteva nekoliko drugačen vidik od institucionalnega pogleda, se pa tudi v tej učenje v okviru procesov HRM pojavlja v vlogi regulatorja. V nasprotju z institucionalnim pogledom pri teoriji transakcijskih stroškov sistem učenja zaposlenih ne skrbi za skladnost organizacijskih procesov z okoljskimi silnicami, temveč je njegova primarna naloga obvladovati konflikte v organizaciji. Procesi učenja imajo s tega vidika vlogo postavljanja nadzornih mehanizmov.

Celovit pogled na problematiko povezave med HRM in uspešnostjo sta z združevanjem RBV, institucionalnega, behaviorističnega in kibernetičnega pristopa ter teorije transakcijskih stroškov poskušala sestaviti Wright in McMahan (1992). Njun model vpliva zunanjih institucionalnih dejavnikov in organizacijske strategije na procese učenja v okviru politik in praks HRM ter posledično učinkovanje na vrednost človeškega kapitala in spremembe vedenja zaposlenih prikazuje Slika 1. Razvidno je, da sta omenjena avtorja nekoliko bolj naklonjena behaviorističnemu stališču, po katerem mora vodstvo organizacije težiti k usklajenosti med strategijo in učenjem v sklopu aktivnosti HRM. 
Slika 1: Strateški kontekst učenja odraslih na delovnem mestu

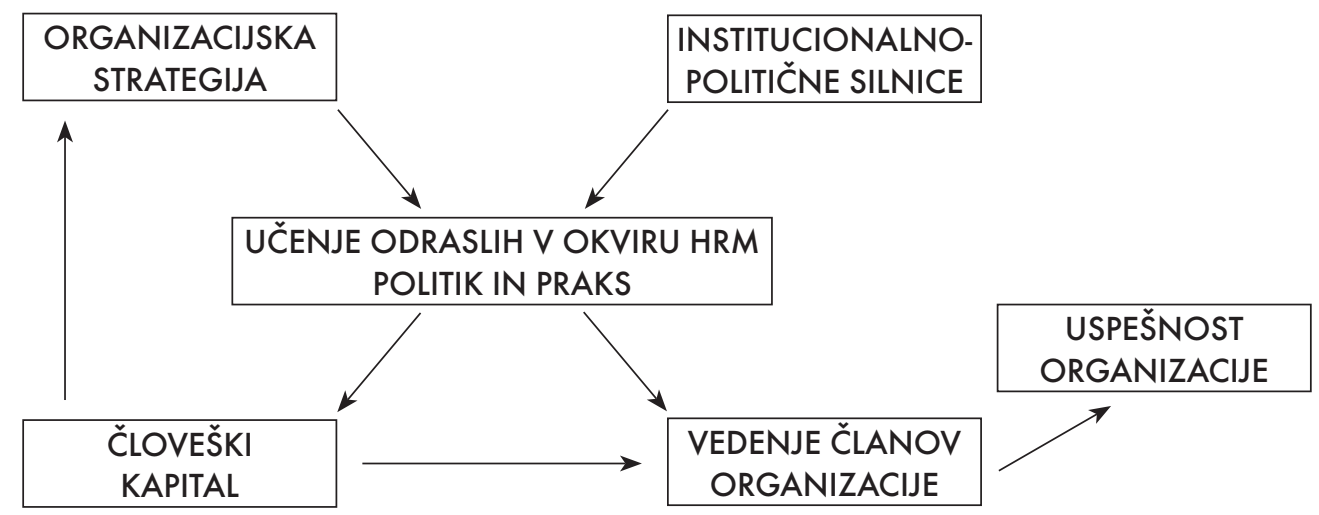

Vir: prilagojeno po Wright in McMahan, 1992, str. 299.

Paauwe in Boselie (2003) sta poskušala narediti sintezo institucionalnega in RBV-pristopa, kar sta podkrepila z empiričnimi dokazi povezanosti treh ravni organizacijskega okolja, in sicer mednarodnega, sektorskega in organizacijskega. Pri tem jima je uspelo pokazati, kako se razlike na treh ravneh organizacijskega okolja izražajo v končnem oblikovanju praks učenja. S tem sta združila inside-out RBV-pristop in outside-in institucionalni model strateškega managementa. Paauwejeva (2004) teza je, da sta možnost strateškega izbiranja $\mathrm{s}$ strani vodstva in posledični manevrski prostor za oblikovanje načrtov učenja v kontekstu sistemov HRM omejena s tremi kontekstualnimi sklopi. V prvi vrsti je to narava produkta oz. trga, na katerem produkt nastopa. Gre za procese, ki opredeljujejo, kako se določen proizvod ali storitev naredi, kako se pride do virov za produkcijo, in specifike, ki obstajajo pri prodaji in uporabi produkta. Drugi sklop dejavnikov se nahaja znotraj organizacije. Tradicija delovanja namreč postavlja vodstvu določene omejitve, zunaj katerih je praktično nemogoče delovati, če so ti dejavniki globoko ukoreninjeni v člane organizacije in so postali del organizacijske kulture. Tretji sklop v Paauwejevem modelu sestavljajo institucionalni mehanizmi, ki vključujejo družbeno, kulturno in pravno komponento, ki vodstvom organizacij postavljajo meje mogočega pri njihovem odločanju. Pri celovitih pristopih lahko opazimo tezo, da koncept najboljših praks in situacijski pristop nista izključujoča. Razlike $\mathrm{v}$ razumevanju delovanja zveze učenje na delovnem mestu-uspešnost, vsaj v kontekstu strateškega HRM, torej vendarle niso tako velike, kot se morda zdi na prvi pogled.

\section{KAJ MERITI NA ORGANIZACIJSKI RAVNI}

Konceptualne razlike pri opredeljevanju učenja odraslih pri delu in posledično tudi pri razumevanju delovanja teh sistemov ter njihovega učinkovanja na uspešnost organizacije so opazne tudi na področju metod raziskovanja oz. načinov merjenja učinkov učenja v okviru politik HRM. V literaturi lahko opazimo številne dileme, kako konkretno meriti sisteme. Najprej se seveda izpostavlja problem, kaj sploh je končni rezultat, ki naj bi ga proces učenja 
dosegel, in s katerimi kazalniki lahko ta končni učinek prikažemo (Bajec, Boštjančič in Tement, 2016). Rejc (2001) poudarja, da je sicer vsak učinek mogoče meriti s stroški, časom, kakovostjo, količino in zadovoljstvom, a se pri vprašanju kazalnikov pogosto omenja razlika med tradicionalnim in sodobnim oz. finančnim in nefinančnim merjenjem uspešnosti.

$\mathrm{Na}$ organizacijski ravni pri profitnih organizacijah še vedno prevladuje t. i. tradicionalno merjenje uspešnosti. Slednje v ospredje postavlja finančni vidik poslovanja, pri čemer sta ključni merili uspeha dobičkonosnost kapitala (ROE) in dobičkonosnost sredstev (ROA). Prvi je predvsem pomembno merilo uspeha za lastnike, medtem ko drugi vključuje pogled na uspešnost uporabljanja vsega, kar ima organizacija na razpolago. Čater (2003) kot finančna merila uspeha navaja tista, ki so izračunana na podlagi denarno izraženih ekonomskih kategorij, predvsem tista, ki so zajeta v temeljnih računovodskih izkazih in jih lahko razdelimo v tri skupine: tradicionalni kazalniki (ROA, ROE), finančni kazalniki razvitih trgov kapitala (rast tržne vrednosti enote kapitala, razmerje med tržno in knjigovodsko vrednostjo kapitala, dobiček na delnico, cenovno-profitno razmerje, dividende, ekonomska dodana vrednost) in finančni kazalniki denarnega toka (stabilnost denarnega toka, razpoložljiv denar itd.). Med finančne kazalnike lahko prištevamo tudi nekatera druga merila, kot so rast prodaje, dodana vrednost na zaposlenega itd. Težava pri teh kazalnikih izhaja iz dejstva, da večinoma temeljijo na prilagodljivi ekonomski kategoriji »dobička«, zato pogosto prikažejo samo posledice, ne pripomorejo pa k ugotavljanju vzrokov. Obenem ne pripomorejo $\mathrm{k}$ spremembi managementa s ciljem odpravljanja problemov, saj sporočajo informacije s časovnim odmikom in ne omogočajo pravočasnih ukrepov (Lothian, 1987). Ravno tako ne upoštevajo, da niso vsi deležniki zainteresirani za maksimiziranje dobička.

Zaradi pomanjkljivosti tradicionalnega dojemanja se je razvilo novo pojmovanje uspešnosti, ki upošteva širši krog različnih interesov, ki naj bi jih organizacija zadovoljevala. Deležniki naj bi bili vsi tisti posamezniki in skupine, ki imajo do organizacije legitimne zahteve, ali pa so prizadeti zaradi njenega delovanja (Donaldson in Preston, 1995). Ker finančni kazalniki sami po sebi ne morejo prikazati koristi vseh udeležencev, tudi če govorimo o profitni organizaciji, se je na teoretični ravni razvila razprava o podpornih merilih uspeha, ki dopolnjujejo finančna merila in izražajo druge vidike uspešnosti (npr. rast, učinkovitost notranjih procesov in vidik kupca) (Kaplan in Norton, 1996). S pomočjo nefinančnih meril je torej mogoča globinska kvalitativna analiza posamezne organizacije in posledično lažje zasledovanje vseh namenov, ki jih opredeljuje organizacijsko poslanstvo. Nefinančni kazalniki so lahko rezultati poslovanja ali pa nefinančni kazalniki dejavnikov, ki vplivajo na končne učinke. Slednji ocenjujejo raven, na kateri se v posamezni organizaciji nahajajo ključni dejavniki uspeha, in so nekakšni znanilci prihodnje uspešnosti.

\section{OPREDELJEVANJE PODROČJA MERJENJA}

V HRM-literaturi še več dilem lahko zaznamo pri vprašanjih, kako opredeliti in spremljati dogajanja ter učinke učenja v okviru HRM na uspešnost (Bondarouk, Trullen in Valverde, 2016; Jiang, Lepak, Hu in Baer, 2012; Woodrow in Guest, 2014). Medtem ko so se 
nekateri osredotočali na učinkovitost izvajanja praks učenja v kadrovskih oddelkih (Teo, 2002), so drugi več pozornosti namenjali razvoju človeškega potenciala in povečevanju vrednosti človeškega kapitala, ki so ga merili prek znanja, veščin in drugih kompetenc članov neke organizacije (Hitt idr., 2001). Do razhajanj prihaja tudi med posamezniki znotraj iste struje. Nekateri namreč menijo, da je učenje v organizacijskem kontekstu treba proučevati globinsko, in sicer prek analize posameznih praks učenja in njihovega prispevka k uspešnosti organizacije (Batt, 2002), medtem ko drugi prisegajo na proučevanje celotnih kompleksov praks učenja, saj naj bi bile te ključni elementi poslovnega procesa (Cappelli in Neumark, 2001). Danes nekoliko prevladuje slednje, saj posamezne prakse lahko ob skupnem delovanju z drugimi povzročajo pozitivne sinergijske učinke, sočasno pa lahko v primeru neusklajenosti govorimo o t. i. smrtonosnih kombinacijah, ko ena aktivnost učenja zmanjšuje vrednost drugi. Ravno zato analiza vpliva posamičnih praks na organizacijo ne more pokazati prave vrednosti skupka praks niti dati pojasnila, kako so te prakse povezane s strategijami. Številni avtorji (npr. Snell, Shadur in Wright, 2002) zato trdijo, da je logika povezovanja aktivnosti učenja veliko pomembnejša za razumevanje strategije HRM od samih aktivnosti, medtem ko je analiza posameznih praks učenja lahko le dodatno orodje pri diagnozi in odpravljanju morebitnih težav v sistemih HRM.

Do razlik ne prihaja le pri opredeljevanju predmeta merjenja, še bolj živa se zdi razprava na področju določanja učinkov, ki jih učenje povzroča na organizacijski ravni. Raziskovalci so se sprva zadovoljevali z enostavnim izračunom korelacije med določeno prakso učenja in finančno uspešnostjo podjetja. Vendar ta tehnika žal le potrdi ali ovrže obstoj zveze med uspešnostjo in konkretnim načinom učenja, ne pojasni pa, ali obstaja neposredna vzročnost $\mathrm{v}$ tej povezavi. Tudi ne pojasni smeri njenega delovanja. Posledično so se pojavile dileme, ali izvajanje učenja vpliva na uspešnost ali pa uspešnost organizacije v večji meri vpliva na način učenja. Tako je Kravetz (1988) trdil, da je narava procesov učenja v okviru HRM odvisna od finančne uspešnosti podjetja. Organizacije, ki imajo več finančnih presežkov, naj bi si namreč lažje privoščile večja vlaganja $\mathrm{v}$ zaposlene ter naj bi ravno tako lahko oblikovanju tega procesa namenile več časa in znanja specialistov. Večina sicer še vedno umešča učenje med vzroke in (ne)uspešnost organizacije opredeljuje kot posledico izvajanja učenja. Deloma je to posledica poteka samega poslovnega procesa, v katerem se najprej določi narava učenja, šele nato se spremlja učinkovitost. Vendar se del te argumentacije skriva tudi v domnevi, da uspešne organizacije ne težijo k spreminjanju dosedanjih praks. Torej naj bi morebitni neuspeh pomenil močnejšo spodbudo za spremembe poteka poslovnega procesa, med drugim tudi vrste učenja. Čeprav so določene raziskave potrdile obstoj povratne vzročnosti (npr. Locke in Latham, 2002), obstaja še vedno kar nekaj skepticizma. Nekatere aktivnosti so sicer bolj dovzetne za povečanje finančnih sredstev (npr. količina in kakovost treninga), vendar na številne dejavnike (npr. kultura in klima) ni možno enostavno vplivati s povečevanjem denarja v organizaciji (Kravetz, 1988). Pološki-Vokić (2003) zato meni, da uspešnost organizacije ne vodi nujno tudi k večjemu interesu za zaposlene s strani vodstva organizacije, enako tudi narava učenja ni izključno posledica povečanega priliva sredstev v organizacijo. 
Pri proučevanju vzročne povezave med učenjem znotraj organizacije in organizacijsko uspešnostjo se pogosto postavlja vprašanje, na kateri ravni meriti učinke učenja. Dyer in Reeves (1995) sta razdelila učinke na neposredni vpliv na človeški potencial (vedenjske spremembe, kot so zadovoljstvo, predanost itd.), rezultate na ravni organizacije (produktivnost, kakovost, ekonomičnost itd.) in finančne rezultate (dobiček, tržni delež, rast prihodkov itd.). Pri tem pa se postavlja kar nekaj dodatnih vprašanj, in sicer:

1) ali naj se učinki učenja spremljajo le na ravni razvoja potenciala in posledičnega povečevanja človeškega kapitala $\mathrm{v}$ organizaciji (prek povečevanja znanja, veščin in preostalih kompetenc);

2) ali naj se spremljajo tudi neposredni učinki na vedenje članov organizacije;

3) ali je smiselno povezovati prakse učenja s končnimi učinki, ki jih spremljamo v zadnji fazi poslovnega procesa.

Naštete dileme prihajajo do izraza predvsem $v$ neprofitnih organizacijah, kjer sprememba finančnega stanja ali tržne vrednosti ne more biti najpomembnejše merilo uspeha organizacije. Nadaljnja težava je odmik med načrtovanim sistemom HRM na strateški ravni, dejansko izvedbo praks učenja in zaznavo teh aktivnosti pri zaposlenih. Ta odmik lahko povzroči, da tri raziskave znotraj iste organizacije pridejo do treh povsem različnih sklepov glede učinkov učenja na organizacijsko uspešnost. Do podobnega problema prihaja tudi zaradi časovne neusklajenosti spremljanja učinkov učenja. Prakse učenja so namreč pri večini študij opazovane $\mathrm{v}$ istem časovnem trenutku kot učinki (Paauwe in Boselie, 2008). S tem je kršeno eno izmed temeljnih načel ugotavljanja vzročno-posledične zveze, po katerem je posledice treba proučevati s časovnim odmikom od proučevanja dejavnikov, za katere predvidevamo, da so vzroki. Prav zaradi navedenih težav obstaja tudi določen dvom o povezavi med načinom učenja in uspešnostjo organizacije, a kljub temu prevladuje prepričanje, da so učinki učenja v kontekstu procesov HRM poleg neposrednih vplivov na vedenje članov organizacije večinoma posredni in se manifestirajo na različne načine na ravni celotne organizacije ter da je zato nujno učinke učenja ocenjevati večplastno.

S ciljem razumevanja in posledično lažjega spremljanja učinkov učenja sta Wright in Nishii (2004) pojasnila sam proces strateškega HRM in psihološke posledice, ki pomenijo posredni dejavnik med učenjem v kontekstu HRM in uspešnostjo. Avtorja sta namreč jasno razlikovala nameravani in uresničeni sistem ter dodala tretji konstrukt, zaznavanje dejanskega sistema, ki nato povzroča reakcije zaposlenih, ki lahko pripomorejo k organizacijski uspešnosti. Poudarjata, da je pri spremljanju učinkov praks učenja potrebna skupinska raven analize, medtem ko je za ocenjevanje psiholoških konstruktov percepcij in reakcij nujno potrebna analiza na individualni ravni. Boselie, Dietz in Boon (2005) so prek obširnega pregleda literature ugotovili, da so obravnave zveze med HRM in uspešnostjo doslej potekale znotraj treh različnih pogledov, in sicer situacijske teorije ter pristopov RBV in AMO (ability, motivation and opportunity to participate). Prav tako je bilo ugotovljeno, da so zaradi različnih kontekstov in teoretičnih konceptov tudi rezultati študij, ki so proučevale neposredne posledice učenja, pogosto vodili do nasprotujočih si sklepov (Lepak, Liao, Chung in Harden, 2006). Posledično nikakor ne moremo trditi, da 
obsežen nabor literature in empiričnih preverb pomeni, da raziskave na področju učinkov učenja znotraj organizacije na organizacijsko uspešnost niso več potrebne. Posebej to velja, če se zavedamo, da je bila večina teh študij izvedena v Združenih državah Amerike in Veliki Britaniji, bistveno manj pa je prispevkov iz evropskih, predvsem posttranzicijskih držav.

Ob tezi, da večja uspešnost organizacije izhaja iz usklajenosti organizacijske strategije in sistema HRM, obstajajo tudi alternativni pogledi na problematiko »črne škatle«. Den Hartog, Boselie in Paauwe (2004) menijo, da so dokazi o zvezi med poslovno strategijo in HRM na eni strani ter med strategijo HRM in praksami učenja na drugi še vedno precej šibki. Po njihovem mnenju naj bi bilo spremljanje in nagrajevanje uspešnosti večinoma $\mathrm{v}$ domeni srednjih oz. linijskih managerjev, zato ravno ravnanje slednjih najbolj določa zaznave zaposlenih o praksah učenja v organizaciji. Paauwe in Boselie (2008) kot razloge za to navajata togost pri opredeljevanju organizacijskih strategij, pri čemer avtorji pogosto ne upoštevajo možnosti hibridnih strategij, ki jih ni mogoče enostavno uvrstiti v delitev diferenciacija/nizki stroški/nišni fokus. Empirično preverjanje povezave med strategijo, sistemom HRM, učenjem in uspešnostjo organizacije je oteženo tudi zaradi relativno dolgega obdobja, ki je potrebno, da se sprememba na strateški ravni pozna v končni uspešnosti. $Z$ večjo statistično veljavo je na drugi strani potrjena vzročno-posledična zveza med praksami učenja in posrednimi dejavniki uspešnosti (npr. produktivnost) (Lepak in Snell, 2002). Ravno ločevanje med neposrednimi in posrednimi posledicami, pri katerih je treba najprej identificirati posrednike učinkov, se zdi ključnega pomena za proučevanje posledic učenja. Pri tem je izrednega pomena ločevanje med merjenjem na organizacijski, skupinski in individualni ravni ter kombiniranje konstruktov, ki izhajajo s perspektive teorij, utemeljenih na znanju, in tistih nekoliko bolj tradicionalnih, ki se fokusirajo na merjenje psiholoških konstruktov.

\section{SKLEPI}

Prispevek prikazuje dileme spremljanja učinkovanja učenja na organizacijsko uspešnost in obenem opisuje glavne dileme, ki se pri tem postavljajo pred raziskovalce. Posledica kompleksnosti spremljanja seveda ne obstaja le na znanstveni ravni, ampak številne težave povzroča tudi v praksi. Stereotipi, da nekaterih procesov učenja ni možno meriti ali kvantificirati, povzročajo problem, ker si managerji ne predstavljajo, koliko koristi jim lahko prinese uvedba določene aktivnosti. Strah pred merjenjem učinkov učenja ni redek, saj vodstva podjetij težko določijo fokus spremljanja, še težje pa je v praksi ustvarjati vzdušje, ki bi bilo temu naklonjeno. Vzroki za to se pogosto skrivajo tudi v nejasnem postavljanju ciljev, kar se neredko konča z izbiro najbolj oportune poti, pri kateri se pogosto uporabljajo nezanesljivi viri in metode obdelave pridobljenih podatkov. Res je, da se v praksi lahko zgodi, da spremljanje ni mogoče zaradi pomanjkanja časa ali sredstev, vendar je to zelo pogosto tudi najbolj uporaben izgovor odgovornih za izmikanje nekoliko zahtevnejšemu delu. Na dolgi rok je spremljanje nujno, ker: 
1) zaposlenim pokaže, katera so pomembna vprašanja, ki se nanašajo na njihovo delo, saj sistemi merjenja omogočajo ločevanje nalog na pomembnejše in tiste nekoliko manj pomembne;

2) pojasnjuje pričakovanja vodstva, saj je nujno postavljanje ciljev in standardov, opredeljenih s stroški, časom, kakovostjo, količino in zadovoljstvom odjemalca, tako da zaposlenim na jasen način opredeli zaželeno vedenje;

3) motivira in spodbuja kreativnost - organizacije sisteme spremljanja uvajajo ravno zaradi želje po povečanju uspešnosti, kar je posledica omogočanja povratnih informacij vsem zaposlenim, ki nato stremijo k izboljšanju svojih dosežkov;

4) olajša administracijo in preverjanje upravičenosti odločitev.

Sama utemeljitev potrebnosti spremljanja učinkov učenja še ne odpravlja številnih dilem. Slednje lahko v določeni meri zmanjšamo, če se držimo nekaterih smernic:

1) Poznati je treba kontekst organizacije, v kateri spremljamo učinke učenja. Treba je poznati cilje organizacije, da lahko (ne)uspešnost sploh izrazimo. Nato pa je potrebno tudi okvirno poznavanje produkcijskega procesa, saj je večina učinkov učenja posrednih in jih običajno lažje ocenjujemo na vmesnih točkah tega procesa.

2) Učinke učenja je treba proučevati večdimenzionalno. To implicira proučevanje učinkovanja učenja na organizacijo z več vidikov, kar zajema okoljske, organizacijske in individualne dejavnike ter posledično vključuje upoštevanje različnih teoretičnih izhodišč.

3) Učinke učenja je treba proučevati na več ravneh. To pomeni izogibanje študijam, ki upoštevajo le en vir informacij, in implicira proučevanje tako nameravanega kot uresničenega stanja po učenju. Pri tem je priporočljivo zajeti mnenja načrtovalcev, izvajalcev in tistih članov organizacije, na katere se določeni procesi učenja nanašajo.

4) Ohraniti je treba enostavnost izvedbe empiričnega preverjanja in razumljivost ugotovitev. Bistvenega pomena za vsako raziskovalno delo je njegova razumljivost, in sicer tako s procesnega kot vsebinskega vidika. Posledično je treba omejiti število dejavnikov, ki jih proučujemo, obenem pa se izogibati mešanju nezdružljivih metod.

\section{REFERENCE}

Bajec, B., Boštjančič, E. in Tement, T. (2016). Človek, delo in organizacija: Pregled psiholoških področij in perspektiv. Ljubljana: Filozofska fakulteta.

Barney, J. (1991). Firm resources and sustained competitive advantage. Journal of Management, 17(1), 99-120.

Batt, R. (2002). Managing customer services: Human resource practices, quit rates, and sales growth. Academy of Management Journal, 45(3), 587-597.

Becker, B. E. in Gerhart, B. (1996). The impact of human resource management on organizational performance: Progress and prospects. Academy of Management Journal, 39(4), 779-801.

Bondarouk, T., Trullen, J. in Valverde, M. (2016). Special issue of international journal of human resource management: Conceptual and empirical discoveries in successful HRM implementation. The International Journal of Human Resource Management, 27(8), 906-908. 
Boselie, P., Dietz, G. in Boon, C. (2005). Commonalities and contradictions in research on human resource management and performance. Human Resource Management Journal, 15(3), 67-81.

Boxall, P. in Purcell, J. (2000). Strategic human resource management: Where have we come from and where should we be going? International Journal of Management Reviews, 2(2), 183-203.

Brečko, D. (2007). Razvoj kariere v učeči se organizaciji. Andragoška spoznanja, 13(1), 58-72.

Cappelli, P. in Neumark, D. (2001). Do "high performance" work practices improve establishment-level outcomes? Industrial and Labor Relations Review, 54(4), 737-775.

Cascio, W. F. (1998). Applied psychology in human resources management (5th ed.). Upper Saddle River, NJ: Prentice Hall.

Celinšek, D. (2015). Pomen, pojavljanje, prevzemanje in prevajanje besede management v slovenščini. Jezikoslovni zapiski, 21(2), 61-83.

Collins, C. J. in Clark, K. D. (2003). Strategic human resource practices, top management team social networks, and firm performance: The role of human resource in creating organizational competitive advantage. Academy of Management Journal, 46(6), 740-751.

Čater, T. (2003). Osnove konkurenčnih prednosti slovenskih podjetij (Doktorska disertacija). Univerza v Ljubljani, Ekonomska fakulteta, Ljubljana.

Delaney, J. T. in Huselid, M. A. (1996). The impact of human resource management practices on perceptions of organizational performance. Academy of Management Journal, 39(4), 919-969.

Den Hartog, D. N., Boselie, P. in Paauwe, J. (2004). Performance management: A model and research agenda. Applied Psychology: An International Review, 53(4), 556-569.

DiMaggio, P. J. in Powell, W. W. (1983). The iron cage revisited: institutional isomorphism and collective rationality in organizational fields. American Sociological Review, 48(2), 147-160.

Donaldson, T. in Preston, L. E. (1995). Stakeholder theory on the corporation: concepts, evidence and implications. Academy of Management Review, 20(1), 65-91.

Dovžan, H. (2003). Izobraževanje v učeči se organizaciji. Andragoška spoznanja, 9(1), 63-70.

Dyer, L. in Reeves, T. (1995). Human resource strategy and firm performance: What do we know and where to we need to go? International Journal of Human Resource Management, 6(3), 656-670.

Fenwick, T. (1998). Questioning the concept of the learning organisation. V S. M. Scot, B. Spencer in A. M. Thomas (ur.), Learning for Life: Canadian Readings in Adult Education (str. 140-152). Toronto: Thompson.

Feurer, R. in Chaharbaghi, K. (1995). Strategy development: past, present and future. Management Decision, 33(6), 11-21.

Hasmath, R. in Hsu, J. (2014). Isomorphic Pressures, Epistemic Communities and State-NGO Interactions. The China Quarterly, 220, 936-954.

Hitt, M. A., Bierman, L., Shimizu, K. in Kochhar, R. (2001). Direct and moderating effects of human capital on strategy and performance in professional service firms: A resource-based perspective. Academy of Management Journal, 44(3), 13-28.

Jiang, K., Lepak, D. P., Hu, J., in Baer, J. C. (2012). How does human resource management influence organizational outcomes? A meta-analytic investigation of mediating mechanisms. Academy of Management Journal, 55(6), 1264-1294.

Kaplan, R. S. in Norton, D. P. (1996). The balanced scorecard: Translating Strategy into Action. Boston: Harvard Business School Press.

Kravetz, D. (1988). The Human Resources Revolution - Implementing Progressive Management Practices for Bottom-Line Success. San Francisco, CA: Jossey-Bass Publishers.

Lazović, S. (2013). Učinkovit menedžment znanja kot podlaga za celosten znanjski inženiring - Znanje kot ključni kapital organizacije. Andragoška spoznanja, 19(1), 79-87. 
Lepak, D. P., Liao, H., Chung, Y. in Harden, E. E. (2006). A conceptual review of human resource management systems in strategic human resource management research. Research in Personnel and Human Resources Management 25(1), 217-271.

Lepak, D. in Snell, S. (2002). Examining the human resource architecture: the relationship among human capital, employment, and human resource configuration. Journal of Management, 28(4), 517-543.

Lipovec, F. (1987). Razvita teorija organizacije. Maribor: Založba Obzorja.

Locke, E. A. in Latham, G. P. (2002). Building a practically useful theory of goal setting and task motivation. American Psychologist, 57(9), 705-717.

Lothian, N. (1987). Measuring Corporate Performance. A Guide to Non-financial Indicators. London: The Chartered Institute of management Accountants.

Mayo, A. (2001). The human value of enterprise: valuing people as assets: monitoring, measuring, managing. London: Nicholas Brealey Publishing.

Možina, S., Jereb, J., Forjančič, J., Svetlik, I., Jamšek, F., Lipičnik, B., ... Merkač Skok, M. (1998). Management kadrovskih virov. Ljubljana: Fakulteta za družbene vede.

Nicolini, D., Gherardi, S. in Yanow, D. (2003). Knowing in Organizations. A Practice-Based Approach. Armonk, London: M. E. Sharpe.

Paauwe, J. (2004). HRM and performance: Achieving long-term viability. New York: Oxford University Press Inc.

Paauwe, J. in Boselie, P. (2003). Challenging »strategic HRM« and the relevance of the institutional setting. Human Resource Management Journal, 13(3), 56-70.

Paauwe, J. in Boselie, P. (2008). HRM and performance: What's next? (delovni dokument). Ithaca, NY: Cornell University, School of Industrial and Labor Relations, Center for Advanced Human Resource Studies.

Pfeffer, J. (1998). The human equation: building profits by putting people first. Boston: Harvard Business School Press.

Pološki-Vokić, N. (2003). Kreiranje višekriterijskog modela za analizu doprinosa managementa ljudskih potencijala uspješnosti poduzeća (Doktorska disertacija). Sveučilište u Zagrebu, Ekonomski fakultet, Zagreb.

Rejc, A. (2001). Spremljanje učinkovitosti izobraževanja v podjetjih. Andragoška spoznanja, 7(4), $116-119$.

Rozman, R. (1996). Kako prevesti »management« v slovenščino: management, menedžment, upravljanje, poslovodenje, vodenje, ravnanje? Organizacija, 29(1), 5-18

Schuler, R. S. in Jackson, S. E. (1987). Linking competitive strategies with HRM management strategies. Academy of Management Executive, 1(3), 207-219.

Skule, S. (2004). Learning conditions at work: a framework to understand and assess informal learning in the workplace. International Journal of Training and Development, 8(1), 8-20.

Snell, S. A., Shadur, M. A. in Wright, P. M. (2002). The era of our ways. V M. A. Hitt, R. E. Freeman in J. S. Harrison (ur.), Handbook of strategic management (str. 627-629). Oxford: Blackwell Publishing.

Snyder, H. (2019). Literature review as a research methodology: An overview and guidelines. Journal of Business Research, 104, 333-339.

Stewart, T. A. (1997). Intellectual capital - the new wealth of organizations. New York: Doubleday/ Currency.

Teo, S. T. T. (2002). Effectiveness of a corporate HR department in an Australian public sector entity during commercialisation and corporatisation. International Journal of Human Resource Management, 13(1), 89-105. 
Van Waeyenberg, T. in Decramer, A. (2018). Line managers' AMO to manage employees' performance: the route to effective and satisfying performance management. The International Journal of Human Resource Management, 29(22), 3093-3114.

Wong, G., Greenhalgh, T., Westhorp, G., Buckingham, J., in Pawson, R. (2013). RAMESES publication standards: Meta-narrative reviews. BMC Medicine, 11, št. članka 20.

Woodrow, C. in Guest, D. (2014). When good HR gets bad results: exploring the challenge of HR implementation in the case of workplace bullying. Human Resource Management Journal, 24(1), 38-56.

Wright, P. M. in McMahan, C. (1992). Theoretical perspectives for strategic human resource management. Journal of Management, 18(2), 295-320.

Wright, P. M., McMahan, G. in McWillams, A. (1994). Human resources and sustained competitive advantage: a resource-based perspective. International Journal of Human Resource Management, 5(2), 301-326.

Wright, P. M. in Nishii, L. H. (2004). Strategic HRM and organizational behavior: integrating multiple levels of analysis. Cornell University (delovni dokument). Ithaca, NY: Cornell University, School of Industrial and Labor Relations, Center for Advanced Human Resource Studies. 